\title{
CRIMES DE GUERRA
}

\author{
José Roberto Franco da Fonseca \\ Professor Associado aposentado da Faculdade de Direito da Universidade de São Paulo
}

Resumo:

Os crimes de guerra só podem ter por sujeito ativo indivíduos. São julgados por tribunais " $a d$ hoc", até que se venha a instalar o recém criado Tribunal Permanente. A sanção cabível é de natureza penal (prisão, perpétua ou temporária). As violações de direitos fundamentais só podem ter por sujeito ativo o Estado. São julgadas por tribunais especiais permanentes (Estrasburgo, França e San Jose da Costa Rica). A sanção cabível é meramente política (sentença de natureza declaratória) ou é também acrescida de condenatoriedade (indenização civil). Crimes de guerra e direitos fundamentais são, assim, matérias que não se devem confundir.

\begin{abstract}
:
Only individuals can practice war crimes, which are punished by "ad hoc" courts. This punishment consists on life or temporary imprisonment. Only States can practice violence against Human Rights. Those States will be judged by special permanent Courts (Strasbourg, France and San Jose of Costa Rica). The defendant State will be submitted either to merely political judicial statements or to civil indemnities charges. Therefore, war crimes and Human Rights are essentially different juridical matters, with different system of legal rules for eachother.
\end{abstract}

Unitermos: crimes de guerra; direitos fundamentais.

\section{Sumário:}

\section{Introdução}

1.1. Importância e atualidade do tema

1.2. Termos em que se coloca o problema e método adequado para sua solução

2. Direito Penal, Interno e Internacional

3. Crimes de guerra: evolução, estrutura e tipologia, juízo e sanções

\subsection{Evolução histórica}

\subsection{Estrutura}

\subsection{Tipologia}

3.4. Juízo competente e sanção cabível 
4. Violação de direitos fundamentais. Evolução, estrutura e tipologia, juízo e sanção

4.1. Evolução histórica

4.2. Estrutura e tipologia

4.3. Juízo e sanção

5. O Direito Internacional Humanitário

5.1. Evolução histórica

5.2. Estágio atual

6. Conclusões

6.1. Crimes de guerra

6.2. Violações de direitos fundamentais ("humanos")

6.3. Direito Internacional Humanitário

1. Introdução

1.1. Importância e atualidade do tema

Em julho de 1998, em Roma, o grupo de trabalho das Nações Unidas conseguiu obter a aprovação de um projeto de estatuto do Tribunal Penal Internacional, a ser sediado em Haia. Houve sete votos contrários, na Conferência (EUA, Israel, China, Filipinas, Índia, Sri Lanka e Turquia), e 21 abstenções.

Tal ocorre, após décadas de exaustivas discussões e sucessivas reuniões da Conferência da ONU sobre prevenção da delinqüência e tratamento de delinqüentes (desde 1980), cujas origens remontam ao projeto elaborado pela Comissão de Direito Internacional das Nações Unidas (1954), seguido de projetos formulados pela Associação Internacional de Direito Penal.

O grande argumento contrário à legitimidade dos tribunais de crimes de guerra que se seguiram ao de Nuremberg (Ruanda, com sede na Tanzânia; e exIugoslávia, com sede em Haia) repousava no princípio de proibição do juízo de exceção, não-natural e não pre-constituído. De feito, os três tribunais internacionais de crimes de guerra foram constituídos "ad hoc" (o primeiro pelos aliados vencedores; os dois últimos pelo Conselho de Segurança da ONU). A consciência jurídica da humanidade reclamava, assim, de há muito, uma Corte permanente (já que o princípio da anterioridade da lei penal não constituía qualquer problema técnico, desde a tipificação operada no Estatuto de Londres, de 8 de agosto de 1945). 
1.2. Termos em que se colocam o problema e o método adequado para sua solução

A discussão do tema naqueles foros, todavia, encontrou duas vertentes de dificuldades sérias, que contribuíram para obnubilar as perspectivas de resultados daqueles trabalhos.

A primeira vertente de dificuldades consiste na própria estrutura dos encontros diplomáticos ocorridos: é da própria essência da atividade diplomática a não-exigência de formação técnico-científica de jurista de seu quadro de profissionais. Os juristas que participaram dos encontros eram, alguns deles, essencial e exclusivamente internacionalistas (sem e domínio da Teoria Geral do Direito Penal), com honrosas exceções.

A segunda vertente deriva do fato de que certos temas de Direito Internacional Público (sendo essa uma característica sedutora desse ramo da ciência jurídica, derivada de seu extremo dinamismo, porque inserido fortemente na dinâmica da História) foram indebitamente apropriados por leigos de todo gênero: desde simples militantes partidários ou de organizações não-governamentais ativistas, passando por profissionais da comunicação escrita e televisiva, até acadêmicos brilhantes em áreas específicas estranhas àquela em que tais temas se inserem. Ora, em matéria de Direito, a contribuição dos conhecimentos empíricos (feitos por imagens, sem abstração de seus elementos individualizadores sensíveis; sem recurso, pois, à transformação das imagens em idéias e conceitos, próprias do conhecimento não-vulgar, científico) muito longe de ajudar, traz confusões e dificuldades que só complicam a equação dos problemas.

O que se viu, então, em escritos nos periódicos e até em palestras nos meios acadêmicos foi algo estarrecedor. A temática dos crimes de guerra foi por alguns alargada e confundida com a dos direitos "humanos" (direitos fundamentais ou essenciais à personalidade), englobando-se, assim, na primeira categoria, uma segunda categoria lógico-científica substancialmente diversa dela (como se recordará). Grupos feministas aventaram que qualquer estupro (cometido por criminoso comum nos longínqüos rincões do interior brasileiro) passasse a ser considerado "crime de guerra" (uma das razões que motivaram o voto contrário dos EUA, que têm soldados sediados em vários pontos do mundo; e de Israel, que, estrategicamente, mantém núcleos de colonização em áreas litigiosas). Houve, até, quem propusesse que essa estratégia de estabelecer colônias fosse tipificada como 
"crime de guerra" (passei a imaginar a preocupação do Chile, que mantém colônias estratégicas na Antártica).

Como dar tratamento adequado ao tema? Obviamente, não é possível tal tarefa senão com a revisão da Teoria Geral do Direito Penal, pois crimes de guerra são espécie do gênero crime. Sem o conhecimento da estrutura tridimensional do crime (gênero), não é admissível se tratar das diferenças específicas do tema em estudo.

De conseqüência, a metodologia adotada neste trabalho desdobrar-seá: a. numa preliminar e introdutória distinção, através de precisões terminológicas, entre "crimes de guerra", "direitos fundamentais" e "Direito Humanitário", três categorias autônomas no Direito Internacional, para se obter a compreensão (específica) e a extensão (genérica) do tema; b. numa segunda fase, já-analítica, a exposição da estrutura, tipologia e jurisdição no atinente, de um lado, aos crimes de guerra, e, de outro lado, aos direitos fundamentais individuais; c. numa terceira fase, a exposição da evolução e estágio atual do Direito Internacional Humanitário (categoria também autônoma com relação às duas anteriores).

\section{Direito Penal, Interno e Internacional}

Uma primeira importante tarefa é definir a topologia dos crimes internacionais, na grande divisão fundamental entre Direito Penal Interno, de um lado, e Direito Penal Internacional, de outro.

Comecemos pelo Direito Penal Interno. Por seu turno, esse corpo de normas desdobra-se em regras de direito substancial, tipos: (a. crimes territoriais; b. crimes transnacionais ou "de caráter internacional") e em regras de direito interespacial ou Sobredireito, atinentes à extraterritorialidade excepcional das regras substanciais internas.

Crimes territoriais são os tipificados nas leis internas, quer codificadas quer extravagantes. Crimes transnacionais ou "de caráter internacional" para adotar a terminologia sugerida por Igor Karpets, são os para cuja execução o agente ou a ação percorrem mais de um território estatal (tráfico de escravos, terrorismo, tráfico de mulheres e crianças, narcotráfico, pirataria, apoderamento ilícito de aeronaves que são os arrolados por Celso Albuquerque Mello - aos quais acrescentaria espionagem e contrabando). São também tipificados no ordenamento jurídico interno, mas sua especificidade consiste no fato de ocorrer, aí, a fixação do juízo 
competente pelo lugar da detenção do agente, quando haja convenção internacional a respeito: de conseqüência, a lei penal aplicável será a "lex fori" (portanto, reafirmase o princípio geral da territorialidade da lei penal).

Já a segunda categoria do Direito Penal Interno, a de regras interespaciais ou de Sobredireito (que o eminente jurista uruguaio Manuel A. Vieira denomina Direito Penal Internacional, antepondo o termo Penal para distingui-lo do Direito Internacional Penal propriamente dito), constitue-se das normas sobre a excepcional extraterritorialidade conferida ao Direito Penal Interno substancial brasileiro, contidas no art. $7^{\circ}$, incs. I (a, b e c), II (b e c), do Código Penal. É o caso de crimes contra a vida ou liberdade do presidente da República ou contra o patrimônio ou fé-pública da União, Estados, Municípios, Distrito Federal e respectivas autarquias ou contra a administração pública brasileira por quem esteja a seu serviço. É também o caso de crimes praticados por brasileiros no Exterior, desde que o agente ingresse no território nacional (caso em que não poderá ser extraditado, em razão de sua nacionalidade).

Se todo esse conjunto constitui o que chamamos Direito Penal Interno, qual será o conteúdo do Direito Penal Internacional?

Comecemos por afirmar que só concebemos como "regras penais internacionais" aquelas que atendam a dois requisitos essenciais: a. natureza internacional da respectiva fonte (tratado ou convenção); b. ação ou omissão que causem dano relevante a bem de que é titular a humanidade ou a sociedade internacional (portanto, delitos "vagos", em que não se leva em conta a individuação das pessoas que sofrem a ação - adotando-se a denominação que para esse caso usam os juristas alemães).

Restringe-se, pois, o âmbito do Direito Penal Internacional aos crimes internacionais ("crimes de guerra"), que são os três grupos tipificados no Estatuto de Londres, de 8 de agosto de 1945, que instituiu o Tribunal Militar "ad hoc" de Nuremberg, a saber: a. crimes contra a paz; b. crimes de guerra em sentido estrito, isto é: atos cometidos no curso da guerra; c. crimes contra a humanidade. 
3. Crimes de guerra: evolução, estrutura e tipologia, juízo e sanções

\subsection{Evolução histórica}

Formulou-se, no mundo cristão medieval, o conceito de "guerra justa" Seus fundamentos foram lançados por Santo Agostinho no século V. ampliados por Santo Isidoro de Sevilha duzentos anos após e confirmados por Santo Tomás de Aquino, no século XIII.

Tais fundamentos serviram de premissas para a argumentação de Francisco de Vitória, ao discutir a justiça ou injustiça da guerra de conquista movida pelos espanhóis na América.

Quando a Europa vivia o sistema multipolar do Concerto Europeu, cientes da fragilidade do equilíbrio de poderes, as potências se reuniram em Haia, em 1899, para uma primeira Conferência da Paz, para evitar a guerra ou, na pior das hipóteses, regular alguns atos de guerra. Numa segunda Conferência, em 1907, celebraram-se diversas convenções (declaração de guerra e armistício; proibição de envolver na guerra os não-combatentes; proibição de ataques a lugares ou populações desprovidos de importância estratégica; proibição de armas e manobras desumanas; o estatuto da neutralidade).

Eclodiu, nesse ínterim, a primeira Grande Guerra.

Terminada esta, o Tratado de Versalhes estipulou (arts. 227 a 230) que o Kaiser seria levado a julgamento por ofensa contra a moralidade internacional e a santidade dos tratados (pois rompera com os acordos da Haia, alegando que a guerra envolvia Estados não-signatários), perante tribunal a ser instalado com cinco juízes (EUA, França, Grã-Bretanha, Itália e Japão). Entretanto, tendo o Kaiser conseguido asilo junto à Holanda, que não o extraditou por entender políticos os crimes a ele imputados, somente alguns militares foram julgados na Alemanha, por tribunais locais.

Em 1920, o comitê de juristas encarregado pela Sociedade das Nações de elaborar o estatuto da Corte Permanente de Justiça Internacional, ancestral da atual Corte Internacional de Justiça, propôs paralelamente a criação de um Tribunal Penal Intérnacional permanente, mas a Assembléia Geral da Liga rejeitou tal proposta. 
O que ocorre é que, até então, a iniciativa da guerra era ato lícito. O que se procurava juridicamente regular eram os atos ("ius in bello") praticados no curso da guerra.

Em 1928, todavia, revolucionam-se tais conceitos, com o Pacto Briand-Kellog: nesse documento, firmado originariamente entre EUA e França, com a adesão posterior de sessenta países (praticamente toda a comunidade internacional de então), passava-se a considerar a iniciativa de guerra como ato ilícito internacional.

Em 26 de junho de 1945, foi assinada a Carta das Nações Unidas, que, em seu artigo $2^{\circ}, \S 4^{\circ}$, proscreve definitivamente a guerra, considerando-a ato ilícito: "os membros da Organização, em suas relações internacionais, abster-se-ão de recorrer à ameaça ou ao uso da força contra a integridade territorial ou a independência política de qualquer Estado"

Concomitantemente, em 8 de agosto, do mesmo ano, instituíram os aliados, pelo Estatuto de Londres, um Tribunal Militar Internacional, sediado "ad hoc" em Nuremberg, para julgar os criminosos de guerra nazistas, composto por quatro juízes (EUA, França, Grã-Bretanha e União Soviética); assim como um segundo Tribunal Militar em Tóquio, com onze juízes, para julgar crimes de guerra cometidos por japoneses.

Em 1949, em Genebra, celebram-se quatro Convenções, numeradas de I a IV, regulando a proteção: a. dos feridos e enfermos na guerra terrestre; $b$. dos feridos, enfermos e náufragos na guerra naval; c. dos prisioneiros de guerra; d. dos civis em tempo de guerra. Era o desdobramento do acervo pactuado na mesma Genebra, em 1864 e em 1925. Consolidava-se, assim, o incipiente Direito Humanitário.

Em 22 de fevereiro de 1993, por meio da resolução n. 808, o Conselho de Segurança da ONU criou o Tribunal Internacional para crimes de guerra cometidos em 1991 na ex-Iugoslávia. Em novembro de 1994, nova resolução do Conselho de Segurança criou Tribunal semelhante para Ruanda. O primeiro seria sediado em Haia e o segundo na Tanzânia. A criação desses dois foros criminais internacionais veio trazer importante inovação na matéria: é que, nos dois casos, ocorreram guerras-intestinas, não interestatais clássicas. Tal evolução, pois, mostra que, no estado atual, o campo de abrangência do Direito Penal Internacional não se limita às guerras entre Estados; ao contrário, suas normas passam a aplicar-se, também, às guerras civis. 
Em julho de 1998, conforme já-antecipado na Introdução deste trabalho, resolveu-se, em Roma, aprovar proposta de grupo de trabalho da ONU, apresentada à Conferência para tal fim, no sentido da criação de um Tribunal Penal Internacional permanente, a ser sediado em Haia.

\subsection{Estrutura}

Como todo delito, o crime de guerra é objeto cultural tridimensional: fato típico, antijurídico e culpável.

Analisemos cada um desses três planos em que se pode escandir a estrutura dessa modalidade criminosa.

No plano do fato típico, temos: a. sujeito ativo; b. ação ou omissão; c. resultado: dano incidente sobre bem jurídico de que é portador ou titular; $d$. adequação típica: subsunção do fato à norma penal. $\mathrm{O}$ sujeito ativo deve agir por vontade livre e deve ser imputável.

Desde logo, observe-se que sujeito ativo somente pode ser a pessoa física. Embora na doutrina alemã (Otto Gierke) e alguns franceses sustentem que a pessoa jurídica é realidade fáctica dotada de vontade própria e autônoma, a tradição do Direito Penal brasileiro nunca aceitou a responsabilidade penal de grupo coletivo de pessoas. A recente edição da Lei n. 9.605, de 12 de fevereiro de 1908 (que dispõe sobre crimes de lesão ao meio ambiente), todavia, representou uma ruptura de tal tradição e, a nosso ver, grave retrocesso cultural (recordando-nos o processo penal pitoresco movido por monges medievos contra a sociedade das formigas, que em caráter continuado furtavam açúcar ao monastério).

Lembre-se, aqui, a ponderação de René Ariel Dotti (in Revista Brasileira de Ciências Criminais, n. 11/201, 1995): "No sistema jurídico positivo brasileiro, a responsabilidade penal é atribuida, exclusivamente, às pessoas fisicas. Os crimes ou delitos e as contravenções não podem ser praticados pelas pessoas juridicas, posto que a imputabilidade jurídico-penal é uma qualidade inerente aos seres humanos" Também Ivette Senise Ferreira ensina: "Sem entrar em considerações a respeito da vontade da pessoa jurídica, se existe ou se é desvinculada da vontade de seus membros, discutida pelos civilistas, as maiores objeções que podemos fazer ao reconhecimento dessa responsabilidade na área penal resumem-se em duas questões fundamentais: a a personalidade das penas, que importa na sua individualização, na medida da culpabilidade do agente; $b$. as 
exigências da verificação da culpabilidade, como juízo de reprovação pessoal, que implica a existência da imputabilidade (condição pessoal), consciência da ilicitude (estado pessoal) e inexigibilidade de outra conduta (só tem conduta a pessoa humana)" (pp. 102-103). A eminente penalista com maestria apontou a consciência da ilicitude, privativa do indivíduo, como o fulcro da teoria da culpabilidade; voltaremos a esse ponto, quando da análise desse terceiro plano do fenômeno tridimensional ora analisado.

Já houve quem, como Pella ("La criminalité collective des États et le Droit Penal de l'avenir" Bucarest, Imprimérie de l'État, 1926, prefácio; "La guerrecrime et les criminels de guerre" in Révue de Droit International des sciences diplomatiques et politiques, Genebra-Paris, Éditions A. Pedone, 1946, pp. 63 e ss.), tenha proposto o Estado como sujeito ativo do crime de guerra. Mas o próprio Pella, que elaborou projeto de Código Penal Internacional como suplemento ao segundo trabalho acima referido, propõe as seguintes sanções (contra Estados): a. diplomáticas (protesto, ruptura de relações); b. jurídicas (seqüestro de bens de cidadãos); c. econômicas (bloqueio, embargo); d. outras (multa, privação de representação em organizações internacionais etc.). Tal proposta recebeu a procedente crítica de Igor Karpets: "se se examina o sistema de sanções proposto pelo Prof. Pella se vê com facilidade que estas não têm nada em comum com os principios do Direito Penal nem com o castigo penal" (pp. 24-25)..

Ademais, se se rememoram os ensinamentos da Teoria Geral do Estado e se se recorda que o Estado não é senão a síntese integrativa resultante de pelo menos três elementos (território, povo e governo), verifica-se cristalinamente que a idéia de um Estado criminoso é um absurdo jurídico, enquanto que governantes criminosos são uma realidade.

Ainda no primeiro plano, o do fato típico, contemplemos agora a figura do sujeito passivo. Como entendemos que se trata de delito "vago" (como atrás já-mencionado), as pessoas mortas, torturadas ou deportadas não são os sujeitos passivos dos crimes de guerra, mas simples objetos materiais da ação delituosa. Sujeito passivo (titular do bem jurídico lesado) é a humanidade, ou a comunidade internacional.

Quanto ao segundo plano estrutural dos crimes de guerra, o da antijuridicidade, formula-se aí juízo de valor, de que a tipicidade é indício, "ratio cognoscendi" (Mayer), ou fundamento, "ratio essendi" (Mezger). 
Quanto ao terceiro plano, o da culpabilidade, nele é que se encontra o grande e definitivo argumento contra a responsabilidade penal das pessoas jurídicas, do Estado em particular. Na teoria da culpabilidade penal, evoluiu-se da mera concepção psicológico-naturalística (que pode até ser suficiente para explicar a vontade, ínsita no plano da tipicidade) para a moderna concepção normativa (Reinhard Frank, Freudenthal, Schmidt, Mezger). O dolo passou modernamente a ser concebido como consciência da antijuridicidade. E consciência, como ensina John Searle, de Berkeley, em publicação recente, é resultado de um processo neurobiológico, exclusivamente admissível no indivíduo. Por isso refere-se Jiménez de Asúa aos "elementos intelectuais" e "elementos afetivos" do dolo, para distinguilo da mera vontade (p. 387).

\subsection{Tipologia}

O Estatuto de Londres, de 8 de agosto de 1945, em seu art. $6^{\circ}$, tipifica três grupos de "crimes de guerra": a. "crimes contra a paz" (direção, preparação, desencadeamento ou prosseguimento de uma guerra de agressão ou de uma guerra de violação dos tratados, concertado ou em conluio para a execução de qualquer um dos atos precedentes); b. "crimes de guerra" em sentido estrito (violação de leis e costumes de guerra: assassinato, maus-tratos ou deportação para trabalhos forçados ou para qualquer outro fim das populações civis nos territórios ocupados, assassinato ou maus-tratos de prisioneiros de guerra ou de náufragos, execução de reféns, pilhagem de bens públicos ou privados, destruição sem motivo estratégico de cidades e aldeias, ou devastações que as exigências militares não-justifiquem); c. "crimes contra a humanidade" (assassinato, exterminação, redução à escravidão, deportação ou qualquer outro ato desumano cometido contra populações civis, antes e durante a guerra; ou, então, perseguições por motivos políticos, raciais ou religiosos, quando esses atos ou perseguições, tenham ou-não constituído uma violação do direito interno dos países onde foram perpetrados, hajam sido cometidos em conseqüência de qualquer crime que entre na competência do Tribunal ou em ligação com esse crime).

Como se vê da tipificação acima, os crimes agrupados sob "b" ("crimes de guerra" em sentido estrito) constituem violações ao chamado "Direito Humanitário", elaborado em Genebra, em 1864 e 1925, depois aperfeiçoado nas Convenções I, II, III e IV, de 1949. 
Já o genocídio subsume-se no grupo dos crimes sob "c" ("crimes contra a humanidade"). A Convenção para Prevenção e Repressão do Crime de Genocídio, assinada em Paris, a 11.12.1948, tornou tal ato ilícito internacional punível mesmo quando cometido em tempo de paz (art. $1^{\circ}$ ), tendo as partes contratantes assumido o compromisso de elaborar, nos seus ordenamentos penais internos, as regras de tipifiçação e cominação de penas adequadas (art. $5^{\circ}$ ).

O Código Penal vigente dispõe, no art. $7^{\circ}$, inciso 1 , alínea "d"; que o crime de genocídio fica sujeito à lei penal brasileira, embora cometido no Exterior, quando o agente for brasileiro ou domiciliado no Brasil, ainda que tenha havido condenação ou absolvição no Exterior. O Anteprojeto governamental de reforma da Parte Especial do Código Penal tipifica o genocídio no título XIV ("Dos crimes contra o Estado Democrático"), capítulo IV ("Dos crimes contra a humanidade"), no art. 396, cominando-lhe pena de reclusão, de oito a quinze anos, além da pena correspondente à violência.

\subsection{Juízo competente e sanção cabível}

Enquanto ao juízo competente para apreciar os crimes de guerra, houve nessa matéria importante evolução.

Os três primeiros tribunais penais internacionais (o da Primeira Guerra, que não chegou a instalar-se; e os de Nuremberg e Tóquio, em 1945) foram criados "ad hoc" pelos aliados vitoriosos e seus integrantes foram por estes designados.

Já o quarto e o quinto (ex-lugoslávia, em 1993, com sede em Haia; e Ruanda, em 1994, com sede na Tanzânia) foram também constituídos "ad hoc" (por falecer um Tribunal Internacional Penal permanente), mas foram instituídos pelo Conselho de Segurança da ONU, que ostenta as seguintes características importantes: a. é órgão internacional, de proeminência na estrutura das Nações Unidas; b. é órgão desinteressado e imparcial quanto aos conflitos (intestinos, repitase) apreciados.

Um terceiro passo, nessa linha de evolução para o aperfeiçoamento e consolidação pragmática do Direito Penal Internacional, seria a criação de Tribunal permanente, o que se noticia ter ocorrido em Roma, em julho de 1998. Como ainda não foi divulgado o inteiro teor das resoluções adotadas a respeito, esperemos que 
esse promissor passo não tenha sido prejudicado por circunstâncias que nosso pessimismo cauteloso apontou na Introdução deste trabalho.

As sanções cabíveis para os crimes de guerra, obviamente, são de natureza penal (morte ou privação, perpétua ou temporária, da liberdade dos indivíduos aos quais foram imputados).

4. Violação de direitos fundamentais. Evolução, estrutura e tipologia, juízo e sanção

\subsection{Evolução histórica}

Desde que se afirmou, no plano do Direito Penal Internacional, que o ser humano, individuadamente considerado, era titular de obrigações (responsabilidade penal) na órbita internacional, era normal que se operasse evolução no sentido reverso da medaiha, isto é: aqueles direitos subjetivos públicos do indivíduo, inerentes à personalidade (portanto, à dignidade humana), oponíveis contra o Estado, podem e devem aspirar a tutela jurídica no plano internacional, nãosó no plano do Direito Público interno.

Em matéria de direitos individuais fundamentais no plano internacional, são tutelados os chamados de "primeira geração" a saber: os que costumam mais freqüentemente sofrer agressões por parte do Estado (vida, integridade física, liberdade de locomoção, liberdade de pensamento e de comunicação, liberdade de associação, liberdade de crença e culto, liberdade de trabalho, liberdade de acesso a/ou participação no poder, igualdade perante a lei).

Em 1949, reuniram-se os países europeus e celebraram uma Convenção de "Direitos Humanos" criando um Tribunal e uma Comissão, sediados em Estrasburgo.

Em 1959, o mesmo modelo foi adotado por Estados americanos, que celebraram Convenção e, em Protocolo anexo, criaram Tribunal e Comissão, sediados em San Jose, Costa Rica.

Usando do Direito Internacional como estratégia, a civilização ocidental vem procurando difundir a aceitação universal de valor cultural fundante de suas regras: o valor da dignidade do ser humano (que se traduz juridicamente por justiça e, no plano internacional, paz e segurança). 


\subsection{Estrutura e tipologia}

Enquanto nos crimes de guerra o sujeito ativo do ato ilícito é sempre um indivíduo, pessoa física (como ficou descrito no ítem 3), em matéria de direitos fundamentais o agente ativo da violação é sempre o Estado, pessoa jurídica de Direito Público. Se o fato for tipificado penalmente no ordenamento interno, não mais se trata de violação de direitos fundamentais, mas crime (homicídio, tortura de preso, castigos corporais praticados por agentes estatais, por exemplo). Nesse caso, não se tratando de violação de direito fundamental mas de crime, o agente não é o Estado, mas o indivíduo, pessoa física, que em seu nome agiu (ilicitamente, em razão de existir o tipo penal). Se a violação não for tipificada como crime no ordenamento interno, só então haverá falar em violação de direitos fundamentais e, por isso, o agente violador é o próprio Estado, pessoa jurídica de Direito Público.

É óbvio que também no caso de o ato ser penalmente tipificado, mas se registre quer a omissão quer a comissão dos órgãos estatais encarregados, produzindo como resultado a impunidade do criminoso, também nesse caso o fato transmuta-se de crime, imputável ao indivíduo, para agressão a direitos fundamentais, imputável agora e como tal ao Estado.

Quanto à tipologia dos direitos fundamentais, remete-se o leitor ao que acima ficou dito (4.1) com referência à sua conceituação. Os direitos fundamentais são os inerentes à personalidade, ao passo que os direitos adquiridos provêm de diversos títulos aquisitivos (compra-e-venda, herança, título de crédito, doação, decreto ou lei estatais, etc.).

\subsection{Juízo e sanção}

No plano do ordenamento jurídico interno, as violações de direitos fundamentais são controladas pelo Poder Judiciário nacional, através de "writs" sumaríssimos ("habeas-corpus" mandado de segurança), ao contrário do que ocorre com os direitos adquiridos, que são tutelados por ações comuns (ordinárias e especiais).

Esgotada a jurisdição nacional e persistindo a violação, a pretensão pode ser levada, por meio de "notitia" à Comissão de San Jose, Costa Rica, se o Estado-violador é membro da Convenção Interamericana de 1959, ou à Comissão de 
Estrasburgo, se o Estado-transgressor for membro da Convenção Européia de 1949. Em qualquer dos casos, a Comissão, após investigações, pode entender que existe "fumus boni iuris" na "notitia"; formada tal "opinio", a Comissão deduz, em nome próprio, a pretensão do autor da notícia perante a Corte de Justiça respectiva. Tratase, como se vê, da figura que a Teoria do Processo denomina "substituição processual" uma vez que a pessoa física ou jurídica não tem legitimidade processual.

Suponhamos, agora, que a vítima não tenha o vínculo pátrio de nacionalidade do Estado-agressor e, mais, que este não seja membro quer da Convenção européia quer da interamericana. Neste caso, o Estado-nacional do ofendido pode exercer-lhe proteção diplomática, através também da substituição processual, mas agora perante a Corte Internacional de Justiça, para ali pleitear, em nome próprio, a condenação indenizatória de interesse de seu súdito ( $v$. casos clássicos "Nottebohm". "Barcelona Traction" e inúmeros outros).

Examinemos, agora, a natureza da sentença e das sanções eventualmente aplicáveis.

A sentença é ou meramente declaratória (carga, aliás, presente preliminarmente em qualquer tipo de sentença, como preleciona Pontes de Miranda), caso em que a sanção, nela implícita, é de natureza política (o Estado é declarado praticante de ato ilícito, por violar obrigação jurídica contraída na Convenção), ou declaratória, acrescida de um "plus" condenatório (sanção indenizatória civil).

Não há cogitar, portanto, de sanções penais (até porque o Estado, réu na ação, não está sujeito a sanção penal), nem o ilícito é penal, senão político).

\section{O Direito Internacional Humanitário}

\subsection{Evolução histórica}

Essa nova dimensão do Direito Internacional Público tem suas origens na atividade desenvolvida por Henri Dunant, que, na batalha de Solferino (em plena guerra entre Áustria, de um lado, e França e Sardenha, de outro, em 1859), ficou horrorizado com atrocidades a que assistiu e, de conseqüência, obteve a convocação de sucessivas reuniões de cidadãos suiços e agentes governamentais, até a criação da Cruz Vermelha Internacional. Embora essa entidade não constituísse uma organização no sentido técnico-clássico (por não ser intergovernamental), inspirou, 
em Genebra, em 22 agosto de 1864, a assinatura de uma Convenção sobre Melhoria de Condições dos Militares Feridos em Campanha.

Durante o século XVIII, havia regras jurídicas costumeiras, que visavam à tutela: a. dos feridos e enfermos; b. dos médicos, enfermeiros e capelães; c. dos hospitais, enfermarias e seus veículos; d. dos prisioneiros de guerra; e. da população civil não-beligerante (J. Francisco Rezek, p. 374).

Em 1899 (primeira Conferência da Paz) e em 1907 (segunda Conferência da Paz), em Haia, estipularam-se regras sobre armas e a atividade dos beligerantes.

A partir dos quatro convênios celebrados em Genebra, em 1949, recebe grande impulso o Direito Internacional Humanitário. Dois Protocolos adicionais às Convenções de 1949 foram assinados em Genebra em 1977: o primeiro (conflitos internacionais) abrange, nessa categoria, as lutas armadas de libertação nacional); o segundo estende as regras jurídicas humanitárias ao campo da guerra civil, intestina (excetuados meros movimentos de insurreição, que não cheguem a caracterizar beligerância).

\subsection{Estágio atual}

Contemporaneamente, o Direito Internacional Humanitário vem tomando rumos, imprevisíveis anteriormente, de grande importância para a realização de seus valores.

Duas vertentes merecem aqui serem referidas. De um lado, têm-se celebrado tratados visando à proscrição de armas químicas e bacteriológicas, desde 1972, aperfeiçoando os sistemas de controle para efetivação das proibições já estipuladas desde o Protocolo de Genebra, de 17 de junho de 1925. Nessa mesma vertente, proíbem-se acesso a tecnologias sensíveis, produção de armas nucleares e realização de testes quer no ar, quer no solo, quer no subsolo ou no mar; ao mesmo tempo, esforçam-se as potências em redução gradativa de seu arsenal nuclear. Revela-se, assim, o Direito Internacional Humanitário como novo e eficiente instrumento de garantia de paz e segurança mundiais.

De outro lado (e essa é uma vertente de desenvolvimento também revolucionário), esse ramo do Direito passou a abranger situações que nada têm, em tese, com a situação típica da guerra. Com efeito, em tempo de paz, novas regras têm surgido para atender às aspirações humanitárias ínsitas no valor próprio do Direito, 
que é a idéia de Justiça. Refiro-me a recentes tratados, que foram assinados ou estão sendo negociados, respeitantemente a transferência de presos condenados, para fins de execução criminal. Inspira-se tal tendência na verificação de que, posto que penalmente condenado, o preso deve ter tratamento humanitário, o que certamente lhe será proporcionado no lugar de sua nacionalidade ou onde tenham domicílio seus familiares.

\section{Conclusões}

\subsection{Crimes de guerra}

- São os únicos crimes "internacionais" Seus tipos (crimes contra a paz, crimes de guerra em sentido estrito e crimes contra a humanidade) têm como modelo de expressão ou cognição o Estatuto de Londres, de 1945, fonte portanto inequivocamente internacional.

- O agente (sujeito ativo) é o indivíduo (penalmente imputável), em cenário de guerra (internacional ou intestina).

- O juízo competente, até o momento, consistiu em tribunais "ad hoc" (Nuremberg montado por beligerantes vencedores; Bósnia e Ruanda montados pelo Conselho de Segurança da ONU). Em Roma, fala-se em Tribunal permanente.

- A sanção cabível é a estritamente penal (morte ou prisão, perpétua ou temporária; tendo sido a primeira excluída para Bósnia e Ruanda).

- Não se confundem com crimes "de caráter internacional", para cuja execução o sujeito ativo ou a ação percorre territórios de vários Estados (tráfico de pessoas, narcotráfico, atos de terrorismo, contrabando, espionagem): estes são crimes tipificados nos ordenamentos internos e o juízo competente é também o nacional do Estado onde for detido o agente.

\subsection{Violações de direitos fundamentais ("humanos")}

- Não são ilícitos penais: a sanção que ensejam é de natureza política (sentença meramente declaratória) ou indenizatória civil (sentença condenatória).

- O agente é sempre unicamente o Estado.

- O juízo competente é a Corte de Estrasburgo (se o Estado é europeu e membro da Convenção de 1949) ou a Corte de San Jose, Costa Rica (se se tratar de membro da Convenção Interamericana de 1959). Se o Estado-violador não for 
membro de nenhum desses tratados e o sujeito passivo da violação for estrangeiro, o Estado-patrial da vítima pode exercitar, perante a Corte Internacional de Justiça, em Haia, a proteção diplomática de seu súdito, pleiteando, no interesse deste, condenção indenizatória civil.

- Se o sujeito ativo do ilícito é agente estatal e o fato está tipificado no ordenamento penal interno, é óbvio que, então, não há falar em direitos fundamentais, mas em mero crime, prevista sanção penal para o agente.

\subsection{Direito Internacional Humanitário}

- Originariamente, circunscrevia-se à consolidação convencional de leis e costumes atinentes à guerra, internacional ou intestina (em Haia e em Genebra). Sua violação, no curso da guerra, subsume-se no tipo previsto como "crimes de guerra em sentido estrito", no Estatuto de Londres, de 1945.

- A moderna tendência desse ramo do Direito Internacional é extrapolar tais lindes, para abranger certas situações em tempo de paz, de que é exemplo a execução das sentenças condenatórias privativas de liberdade impostas a criminosos domiciliados no Exterior, propiciando-se a transferência de presos estrangeiros.

São Paulo, setembro de 1998.

7. Bibliografia

ACCIOLY, H. e SILVA, G. E, do Nascimento e. "Manual de Direito Internacional Público" S. Paulo, Saraiva, $12^{\mathrm{a}}$ ed., 1996.

ASUA, Luis Jiménez de. "La ley y el delito" Buenos Aires e México, Ed. Hermes, $2^{\mathrm{a}}$ ed., 1954.

BASSIOUNI, Cherif M. "International Criminal Law" Nova Iorque, Transnational Publishers Inc., 1986-7, 3 vs.

BLISCHENKO, I. e ZHDANOV, N. "El terrorismo" trad. de M. Ciutat, Moscou, Ed. Progresso, 1983.

BONAVIDES, Paulo. "A nova universalidade dos direitos fundamentais", in "Nomos" Fortaleza, vs. 9-10, ns. 1 e 2, jan.-dez. 1990 e 91.

BRUNO, Aníbal. "Direito Penal" t. I, Rio de Janeiro, Forense, $4^{\mathrm{a}}$ ed., 1984. 
CONOT, Robert. "Justice at Nuremberg", Nova Iorque, Harper \& Row, 1983.

COOPER, Robert W. "The Nuremberg Trial" Nova Iorque, Penguin, 1947.

FERREIRA, Ivette Senise. "Tutela penal do patrimônio cultural" S. Paulo, Rev. Tribs., 1995.

FONSECA, J. R. Franco da. "Dimensão internacional dos direitos fundamentais da pessoa". in "Revista da Faculdade de Direito", S. Paulo, 1993, v. 88, pp. 487 e ss.

GARCIA AMADOR, F V. "Dimensiones actuales del Derecho Internacional Público" (comunicação ao XVII Congresso), IHLADI, Madri, 1992.

KARPETS, Igor. "Delitos de caráter internacional" trad. de Pérez Castul, Moscou, Ed. Progreso, 1983.

LAFER, Celso. "A reconstrução dos direitos humanos: um diálogo com o pensamento de Hannah Arendt" S. Paulo, Cia. das Letras, 1991.

LEWANDOWSKI, Enrique Ricardo. "Proteção dos direitos humanos na ordem interna e internacional" Rio de Janeiro, Forense, 1984.

LUNA, Everardo da Cunha. "Estrutura juridica do crime", Recife, UFPe, 1970.

MELLO, Celso de Albuquerque. "Direito Penal e Direito Internacional" Rio de Janeiro, Freitas Bastos, 1978.

. "Introdução ao estudo da sanção no Direito Internacional Público", Rio de Janeiro, Univ. Gama Filho, 1995.

PELLA, Vespasien V "La criminalité collective des états et le droit pénal de l'avenir" Bucarest, Imprimérie de l'État, 1926.

"La guerre-crime et les criminels de guerre". in "Révue de Droit International des sciences diplomatiques et politiques", Genebra-Paris, Éd. A. Pedone, 1943, pp. 63 e ss.

RANGEL, Vicente Marotta. "A Declaração Universal dos Direitos do Homem em seu vigésimo aniversário" in "Problemas Brasileiros", S. Paulo, n. 70, 1969.

"Direito e Relações Internacionais" S. Paulo, Rev. Tribs., 5a ed., 1997.

REALE, Miguel. "Introdıção à Filosofia". S. Paulo, Saraiva, 1988.

REALE JÚNIOR, Miguel. "Antijuridicidade concreta" S. Paulo, J. Butschatsky, 1973.

REZEK, J. F "Direito Internacional Público" S. Paulo, Saraiva, 1989.

RIPOLLÉS, Antonio Quintano. "Tratado de Derecho Penal Internacional e Internacional Penal" Madri, Instituto F de Vitoria, 1955. 
SMITH, Bradley F "O Tribunal de Nuremberg" trad. de Henrique de Araújo Mesquita, Rio de Janeiro, Francisco Alves, 1979.

TAYLOR, Telford. "The anatomy of the Nuremberg Trials" Nova Iorque, Knopf, 1992.

VIEIRA, Manuel A. "Derecho Internacional Penal y Derecho Penal Internacional" Montevideo, Fundación de Cultura Universitaria, 1969.

WELZEL, Hans. "Derecho Penal Alemán", trad. J. B. Ramirez e S. I. Perez, Santiago, Ed. Juridica, $3^{a}$ ed. espanhola, 1987. 